\title{
Assessment and utilization of some Egyptian clay deposits for producing lightweight concrete
}

\author{
Ali Ismail ${ }^{1}$, Hamed Mekky ${ }^{1}$, Mohamed Saad Elmaghraby ${ }^{2}$ \\ ${ }^{1}$ Geological Sciences Department, National Research Center, Egypt \\ ${ }^{2}$ Ceramic Department, National Research Center, Egypt
}

Email address:

mselmaghraby@yahoo.com (M. S. Elmaghraby)

\section{To cite this article:}

Ali Ismail, Hamed Mekky, Mohamed Saad Elmaghraby. Assessment and Utilization of Some Egyptian Clay Deposits for Producing Lightweight Concrete. International Journal of Materials Science and Applications. Vol. 3, No. 3, 2014, pp. 79-83. doi: 10.11648/j.ijmsa.20140303.11

\begin{abstract}
The clay materials were collected from Fayoum area (F- type) and Alamine area (A- type and S- type). Swelling and PH measurnments for the selected raw clay materials were measured. Chemical and mineral composition was investigated using XRF and XRD, respectively. Chemical analysis confirms that $F$ type has higher alumina than the other two types of clay A and S. Kaolinite is an essential mineral in F type while it occurs in minor amount in A and S types. Montmorillonite detected classified into calcium montmorillonite and sodium montmorillonite. Calcium montmorillonite is observed in $\mathrm{F}$ type while sodium montmorillonite is detected in both samples of $\mathrm{S}$ and A types. PH value results refer to the $\mathrm{F}$ type is slightly below 7 while the $\mathrm{S}$ and A types are above 8 . Swelling measurements showed also different values in the three types of clay materials reaching a value of 300\% in S- types 100\% in soil A and 50\% in F- type. The data of swelling and PH confirm the distribution of montmorillonite in the three types of clay materials. The bloataility of the fired granules in term of density show that the lowest density for $A$ and $S$ types $\left(0.84\right.$ and $0.65 \mathrm{~g} / \mathrm{cm}^{3}$ at $1150^{\circ} \mathrm{C}$ respectively.) compared with the F type $\left(1.75 \mathrm{~g} / \mathrm{cm}^{3}\right)$ at $1200^{\circ} \mathrm{C}$. XRD patterns of the fired clay samples confirm that A and S mainly composed of quartz and hematite as well as some albite in restricted to A type. F sample record mullite in addition to the cristobalite and quartz. Lightweight concretes blocks of low density and relatively good strength are tested for producing and utilized in modern building trend for dead-load construction and wall construction were prepared from clay materials under investigation by firing the $\mathrm{A}$ and $\mathrm{S}$ types up to $1150^{\circ} \mathrm{C}$ using a rate of heating $20^{\circ} \mathrm{C} / \mathrm{min}$.
\end{abstract}

Keywords: Clay Minerals, Clay Swelling, Bloatability of Clay, Light Weight Concretes

\section{Introduction}

Clay deposits are widely distributed within many geological formations beginning from carboniferous to recent age. They occur around Nile valley and Delta as well as in the Eastern and Western Desert. Most of these occurrences were geologically studied, assessed for application in many ceramic industries, namely refractories, white ware, heavy clay products and Portland cement ${ }^{(1)}$.

Clays applied in the manufacture of ceramic products are classified according to their chemical, mineral and particle size composition as well as properties ${ }^{(2-6)}$. They indicated that kaolinite rich clay are refractory with low plasticity, long vitrification range and white to buff burning colour as well as low drying and firing shrinkage. On the other hand, montmorillonite rich clays are non refractory with high plasticity, short vitrification range and buff to red burning colour as well as high drying and firing shrinkage. The illite rich clays are intermediate between kaolinite and montmorillonite - rich clays and vary over a wide range.

Lightweight clay aggregates are usually produced by firing pellets of some low grade clays with or without addition up to the vitrification range. At this stage of firing the clay pellets expand or bloat owing to release of gases within firing bodies in the presence of the liquid phase. On coaling, it preserves the cellular texture and lightweight aggregate is obtained. The bloating process should occur below $1300^{\circ} \mathrm{C}$ for clays of any commercial use ${ }^{(7-10)}$.

Mechanisms and factors controlling bloating of clays have been investigated in a number of studies ${ }^{(11-15)}$. Riley (1951) estimated limits of fluxing components (exclusive of volatile and minor constituents and expressed as oxides) necessary to produce a viscous material within the $1093^{\circ} \mathrm{C}$ to $1315^{\circ} \mathrm{C}$ range as about 25 to 40 percent. The role of $\mathrm{PH}$ in bloating is 
significant in that it is an empirical indication of the amount of potential flux and gas forming materials in the clay as average PH of non bloating clays as 4,4 and bloating clays as 6,6 and a general increase of bloating incidence with increase in $\mathrm{PH}^{(16)}$.

The scope of the research paper is to investigate the possibility of utilization of some expanded clays available in Egypt as lightweight concrete. Physical, mechanical, mineralogical and chemical tests are done for clay rich materials. Clay materials collected from different localities were fired to select the optimum temperature required to produce light-weight aggregates at lowest density for the production of lightweight aggregates.

\section{Materials and Methods}

The materials used in this work were three clay samples collected from two localities; namely, Fayoum area (F- type) and Alamine area (A and $\mathrm{S}$ types). $\mathrm{F}$ and A types are mainly natural without treatment while $\mathrm{S}$ - type is soda treated bentonite- rich clay. These samples were investigated for their chemical, mechanical and physical as well as mineralogical composition.

$30 \mathrm{~kg}$ of the three bentonite- rich clay samples were separately ground using a steel ball mill then passed through $100 \mu \mathrm{m}$ sieves. Ball pellets of 2 to $5 \mathrm{~mm}$ diameter were prepared from each sample by atomized spray of slow addition of water whilst the fine powders of the clay were turned over in a rotary drum mixer. The green pellets were then dried for $48 \mathrm{~h}$ in open air to allow the water of workability to release and fired after that in a muffle furnace with a rate of $20^{\circ} \mathrm{C} / \mathrm{min}$ for 1 hour at 1000,1050 , 1100,1150 and $1200^{\circ} \mathrm{C}$ to test the best temperature that yield the lowest density and higher bloatability without completely melting of the pellets. The bloatability of the investigated clay pellets were followed by the bulk density of the fired samples using Quantachrome Corporation Upyc 1200e v5. 03. The physico-mechanical properties of the fired briquettes in terms of bulk density, firing shrinkage and crushing strength were investigated. Also, phase composition was determined by XRD after firing up to $1150^{\circ} \mathrm{C}$.

\section{Results and Discussion}

\subsection{Composition of the Clay Samples}

Table 1 summarizes the chemical analysis data of montmorillonite rich clay samples collected from Fayoum (F) and Alamine $\{(\mathrm{A}$ and $\mathrm{S}$ - types $)\}$. The data was recalculated as shown in the same table. It is evidence that the three samples contents of silica are located within a narrow range, since it is range from $58.30 \%$ in $\mathrm{F}$ type to $59.49 \%$ and $59.31 \%$ in both $\mathrm{S}$ and A types, respectively. While alumina has a wide range from the low content at $\mathrm{A}$ and $S(15.48 \%$ and $16.90 \%$, respectively to the higher content observed at $\mathrm{F}(24.80 \%)$. TIO content is the sum of $\mathrm{TiO}_{2}, \mathrm{Fe}_{2} \mathrm{O}_{3}, \mathrm{CaO}, \mathrm{MgO}, \mathrm{Na}_{2} \mathrm{O}$ and $\mathrm{K}_{2} \mathrm{O}$. $\mathrm{F}$ type show the minimum content of the TIO (16.9) and increase in the S type $(22.52 \%)$ and record the maximum content at A type (25.01\%). F type has the lower and higher content of TIO and alumina, respectively. While $\mathrm{A}$ and $\mathrm{S}$ types show the lower and higher alumina and TIO content, respectively. Loss on ignition for the three samples shows no significance and slight difference. It ranges between 8.15 to $9.54 \%$.

Figure 1 exhibits the XRD patterns of the studied clay samples. These patterns confirm that they are mainly composed of montmorillonite and kaolinite clay minerals as well as quartz as non clay mineral. No evident for the presence crystalline illite clay mineral, carbonate or other oxides as non clay mineral. Kaolinite is recorded as essential mineral in $\mathrm{F}$ type, while with minor content in A and $S$ types. Detected montmorillonite was classified into calcium montmorillonite and sodium montmorillonite. Calcium montmorillonite is observed in $\mathrm{F}$ type while sodium montmorillonite is detected in both samples of $\mathrm{S}$ and A types. Swelling values show different values of the clay materials under study reaching a value of $300 \%$ in Stypes $100 \%$ in soil A and $50 \%$ in F- type which confirmed the distribution and type of montmorillonite in three clay types.

The PH values of the clay suspensions in water were determined to in an attempt to have a view on the bloating characteristic of the clay. Results determined using a $\mathrm{PH}$ electrode instrument as illustrated in table 2. These results refer to the F type is slightly below 7 which mean that is neutral while the $\mathrm{S}$ and $\mathrm{A}$ samples are above 8 which indicate that is slightly basic. This might be taken as indication to the presence of sodium montmorillonite rich clay.

The chemical composition data of the three clay samples are recalculated on calcined basis and plotted on the Riley's composition diagram to try to evaluate the bloating shape of these samples, since fluxing oxide are plotted against silica and alumina. All samples exist in the field of bloating as shown in Figure 2

Table 1. Chemical composition of the studied clay samples.

\begin{tabular}{cccc}
\hline $\begin{array}{c}\text { Oxides } \\
\mathbf{W t} \%\end{array}$ & Fayoum clay & $\begin{array}{c}\text { Soda- treated } \\
\text { clay }\end{array}$ & Alamine clay \\
\hline $\mathrm{SiO}_{2}$ & 52.14 & 53.12 & 51.13 \\
$\mathrm{TiO}_{2}$ & 1.34 & 1.15 & 1.31 \\
$\mathrm{Al}_{2} \mathrm{O}_{3}$ & 22.16 & 15.98 & 13.35 \\
$\mathrm{Fe}_{2} \mathrm{O}_{3}$ tot & 7.75 & 9.24 & 11.56 \\
$\mathrm{MnO}$ & 0.18 & 0.04 & 0.04 \\
$\mathrm{MgO}$ & 1.93 & 3.77 & 3.98 \\
$\mathrm{CaO}$ & 0.43 & 0.81 & 0.72 \\
$\mathrm{~K}_{2} \mathrm{O}$ & 1.10 & 0.83 & 0.89 \\
$\mathrm{Na}_{2} \mathrm{O}$ & 2.39 & 4.26 & 3.09 \\
$\mathrm{P}_{2} \mathrm{O}_{5}$ & 0.10 & 0.14 & 0.14 \\
$\mathrm{SO}_{3}$ & 0.72 & 0.76 & 0.66 \\
$\mathrm{Cl}$ & 0.12 & 1.45 & 1.32 \\
$\mathrm{LOI}$ & 9.54 & 8.15 & 8.57 \\
$\mathrm{On}$ Calcined basis & & \\
$\mathrm{SiO}_{2}$ & 58.3 & 59.49 & 59.31 \\
$\mathrm{Al}_{2} \mathrm{O}_{3}$ & 24.8 & 17.89 & 15.48 \\
$\mathrm{TFO}^{5}$ & 16.9 & 22.52 & 25.01 \\
\hline
\end{tabular}


Table 2. PH values of the clay-water suspensions.

\begin{tabular}{cc}
\hline $\begin{array}{c}\text { Clay-water suspensions } \\
(\mathbf{1 : 2 5})\end{array}$ & $\begin{array}{c}\text { PH Values determined after 24 } \\
\text { hours }\end{array}$ \\
\hline Blank & 6.68 \\
Fayoum clay & 6.30 \\
Soda- treated clay & 8.95 \\
Alamine clay & 8.56 \\
\hline
\end{tabular}

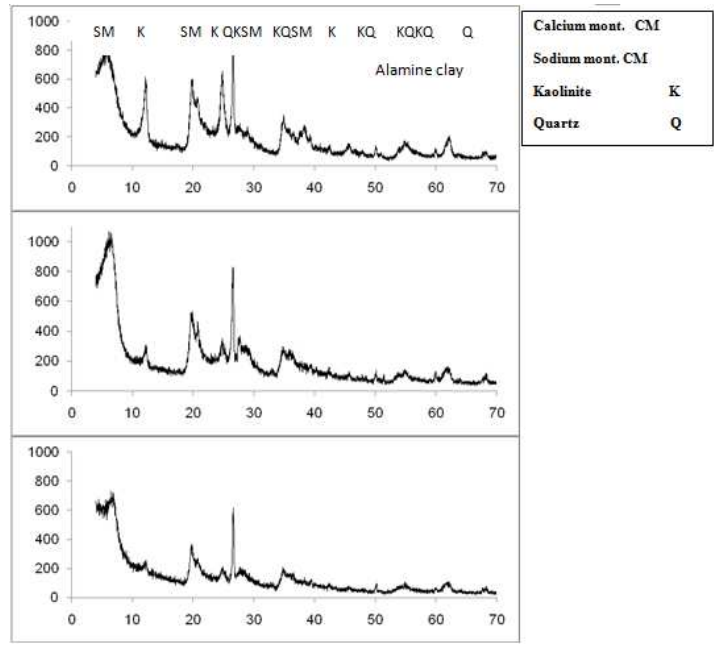

Figure 1. XRD patterns of the studied raw clays.

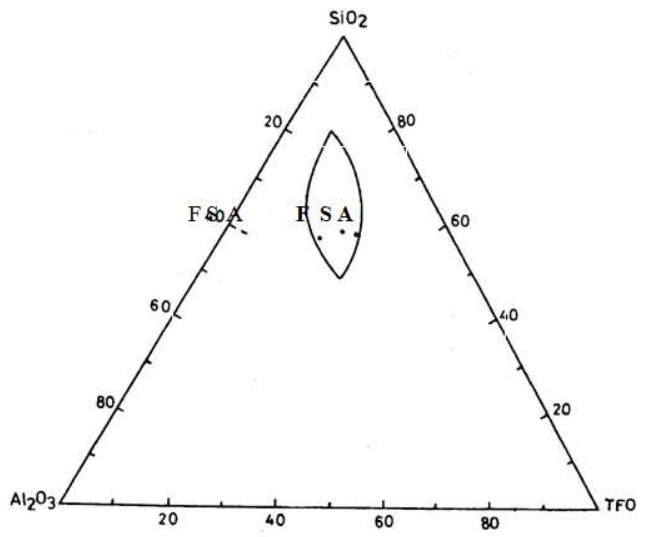

Figure 2. Ternary $\mathrm{Al}_{2} \mathrm{O}_{3}-\mathrm{SiO}_{2}$ - total fluxing oxide composition diagram \{after Riley 1951\}.
Abbreviations:
F Fayoum clay
S Soda- treated clay
A Alamine clay

\subsection{Bloatability of the Clay Samples}

The bloatability of the investigated clay materials were followed by determining the bulk density of the fired pellets using Quantachrome Corporation Upyc 1200e v5. 03. The results of the bulk density of the fired pellets are represented as a function of firing temperature from 1000 up to $1200^{\circ} \mathrm{C}$ as shown in Figure 3. From these results, it is shown that the bulk density decrease by increasing temperature. Minimum bulk density which reflects the highest bloating is observed in $\mathrm{A}$ and $\mathrm{S}$ types at $1150^{\circ} \mathrm{C}$. On further heating at $1200^{\circ} \mathrm{C}$ both sample show partially melt.
So the optimum temperature for the A and S type is $1150^{\circ} \mathrm{C}$ with bulk density 0.84 and $0.65 \mathrm{~g} / \mathrm{cm}^{3}$, respectively. On the other hand, F- type shows a slight increase in bloating which reflect the slight decrease in the density up to $1200^{\circ} \mathrm{C}\left(1.75 \mathrm{~g} / \mathrm{cm}^{3}\right)$. After that no appreciable change is notice.

The density results showing that, lowest density for A and $\mathrm{S}$ type compared with the $\mathrm{F}$ type at $1150^{\circ} \mathrm{C}$. This may be attributed to the higher TIO of the A and S types (25.01 $\& 22.52 \%)$, respectively than the F type (16.90\%), which reflect that $\mathrm{A}$ and $\mathrm{S}$ types are found to contain much $\mathrm{FeO}$ in the lattice of their montmorillonite, the dominant clay mineral in these clays. The $\mathrm{FeO}$ is oxidized in the temperature range $600-800^{\circ} \mathrm{C}$ at the expense of the hydroxyl groups of the clay mineral in to $\mathrm{Fe}_{2} \mathrm{O}_{3}$. The ferric oxide is subsequently dissociated on further firing at 800 $1200^{\circ} \mathrm{C}$ into magnetite $\mathrm{Fe}_{3} \mathrm{O}_{4}$ and oxygen gas. Therefore it has been expected that the bloating of these clays might be continued above $1000^{\circ} \mathrm{C}$ and up to $1200^{\circ} \mathrm{C}$.

While calcium montmorillonite is recorded in $\mathrm{F}$ type show less bloatability than sodium montmorillonite recorded in the other types.

Figure 4 exhibits the XRD patterns of the fired clay samples. These patterns confirm that $\mathrm{A}$ and $\mathrm{S}$ mainly composed of quartz and hematite as well as some albite restricted to A type. F sample record mullite in addition to the cristobalite and quartz. No evidence for the mullite in the $\mathrm{A}$ and $\mathrm{S}$ type as well as hematite in the $\mathrm{F}$ type, this may due to the small amount of alumina and total iron recorded in both $\mathrm{A}$ and $\mathrm{S}$ types as well as $\mathrm{F}$ type, respectively as confirmed in table 1 .

According to the obtained results, it is concluded that lightweight aggregates of low bulk density could be produced by firing the $\mathrm{A}$ and $\mathrm{S}$ samples up to $1150^{\circ} \mathrm{C}$ using a rate of heating $20^{\circ} \mathrm{C} / \mathrm{min}$. The bulk density of the bloated clay aggregates that used in lightweight concretes ranges between 0.55 to $1.05 \mathrm{~g} / \mathrm{cm}^{3}$ according to the British specification $^{(17)}$.

\subsection{Lightweight Concrete}

To produce lightweight concrete blocks from the selected fired aggregates of $\mathrm{S}$ and $\mathrm{A}$ types, the aggregate used in these mixes are following the British specification No. 2028, should have bulk density between 0.55 and 1.05 $\mathrm{g} / \mathrm{cm} 3$ and grain size between $5-20 \mathrm{~mm}$ with no fine. Also the mix design leads to best properties as shown in table 3 .

The aggregates and cement was dry mix then mix with water using mechanical mixer, the concrete was molded in $5 * 5 * 5 \mathrm{~cm}^{3}$. The mould was placed on a vibratory table to remove any air bubble or voids and give the best compaction for the blocks. The moulds were cured in a cabinet of $100 \%$ relative humidity for $24 \mathrm{~h}$ till sufficient strength has developed. The cubes were then demoulded and cured under water for 28 day as shown in figure 5 . The bulk density and shrinkage as well as crushing strength of the concrete cubes were determined and illustrated in table 3 to assess their suitability for building purposes. 


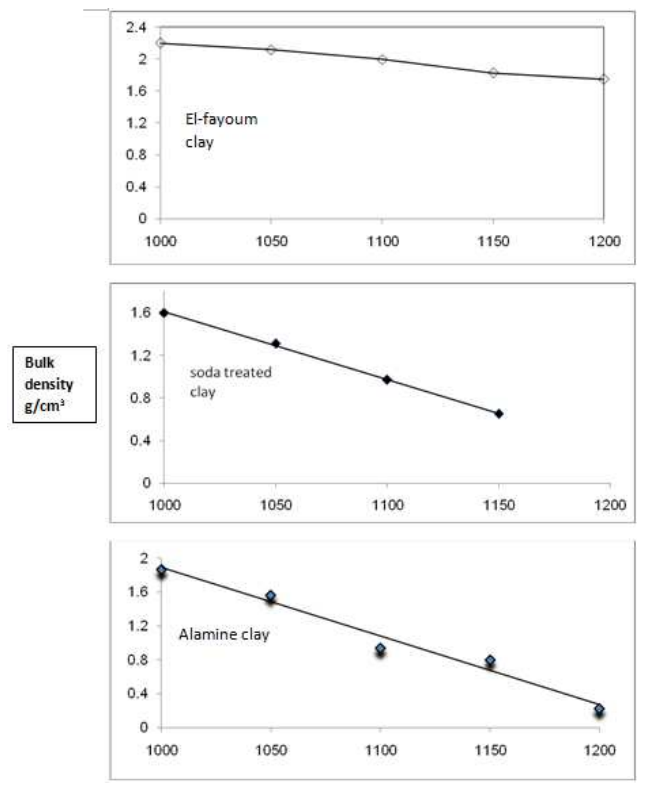

Firing temperature ${ }^{\circ} \mathrm{C}$

Figure 3. Bulk density in relation to the firing temperature of the different types of the clay samples.

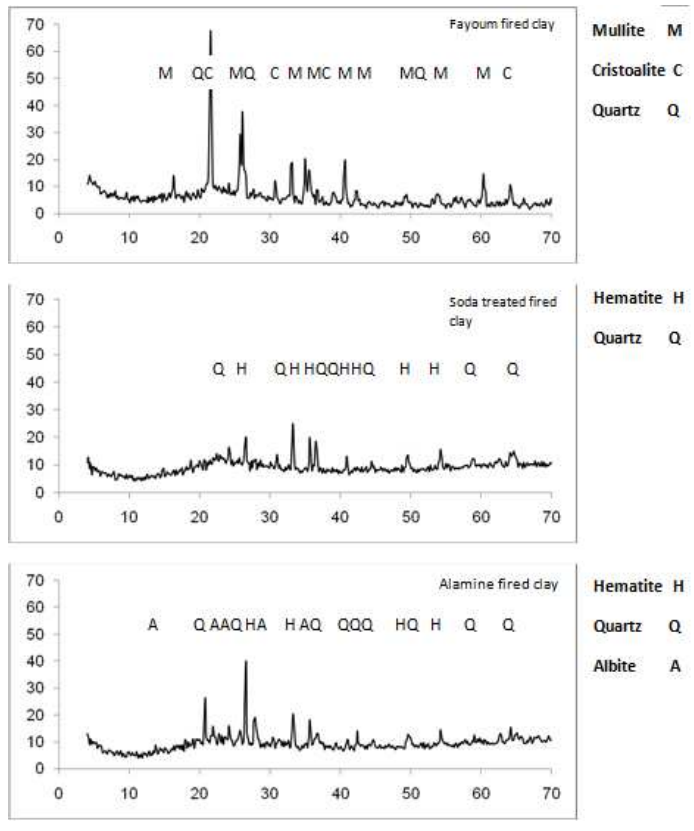

Figure 4. XRD patterns of the studied clays fired at $1150^{\circ} \mathrm{C}$

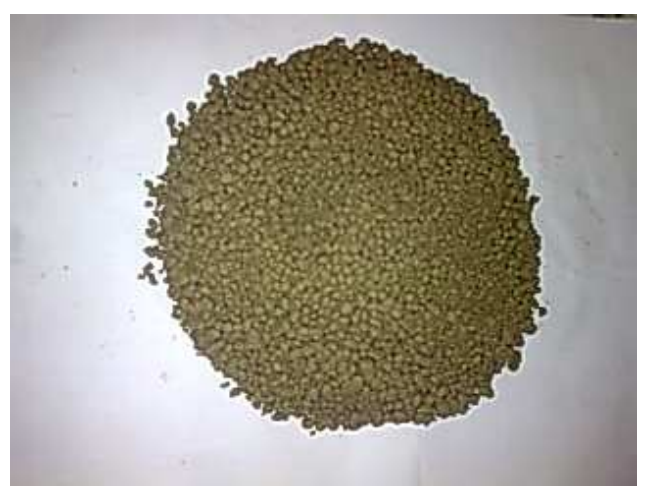

(A)

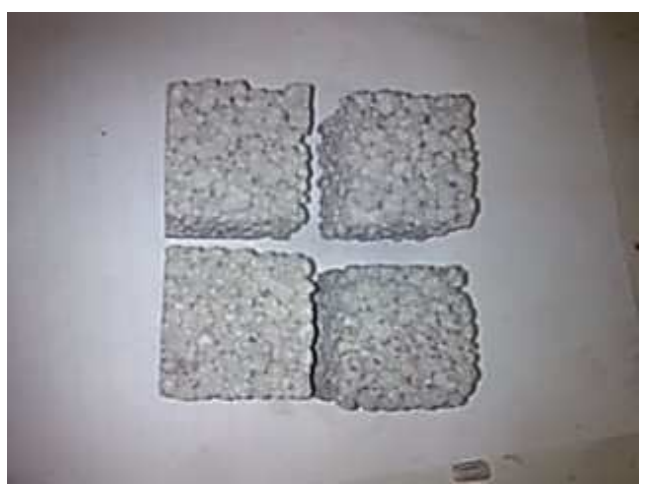

(B)

Figure 5. photograph of the green clay granules $(A)$ and concretes $(B)$

Table 3 summarizes the mix composition and some properties of the prepared lightweight concretes. The bulk density of the concretes of the two types is range between $0.65 \mathrm{~g} / \mathrm{cm}^{3}$ in $\mathrm{S}$ type to $0.67 \mathrm{~g} / \mathrm{cm}^{3}$ in A type while the shrinkage show 0.20 and $0.16 \%$ for the $S$ and A type, respectively. The crushing strength of the both types after curing for 28 days is located within a narrow range as $37 \mathrm{~kg} / \mathrm{cm}^{2}$ for $\mathrm{S}$ and $39 \mathrm{~kg} / \mathrm{cm}^{2}$ for A types, respectively.

The above results indicate the possibility of producing lightweight concretes blocks of low density and relatively good strength could be utilized in modern building trend for dead - load construction and in partition - wall construction as well as improve the thermal insulation of buildings.

Table 3. mix composition and properties of the prepared light weight concrete.

\begin{tabular}{|c|c|c|c|c|c|c|c|}
\hline \multicolumn{2}{|c|}{ Mix composition } & \multicolumn{2}{|c|}{ Bulk density $\mathrm{g} / \mathrm{cm}^{3}$} & \multicolumn{2}{|c|}{ Shrinkage $\{\%\}$} & \multicolumn{2}{|c|}{ Crushing strength $\mathrm{Kg} / \mathrm{cm}^{2}$} \\
\hline $\begin{array}{c}\text { Aggregate } \\
\text { /cement ratio by } \\
\text { volume }\end{array}$ & $\begin{array}{c}\text { Water/cement ratio } \\
\text { by weight }\end{array}$ & $\begin{array}{l}\text { Soda- treated } \\
\text { clay }\end{array}$ & Alamine clay & $\begin{array}{c}\text { Soda- treated } \\
\text { clay }\end{array}$ & Alamine clay & $\begin{array}{c}\text { Soda- treated } \\
\text { clay }\end{array}$ & Alamine clay \\
\hline $6: 1$ & 0.4 & 0.65 & 0.67 & 0.20 & 0.16 & 37 & 39 \\
\hline
\end{tabular}

\section{Conclusions}

4.1. Chemical analysis confirms that $\mathrm{F}$ type has the lower and higher content of TIO and alumina, respectively. While $\mathrm{A}$ and $\mathrm{S}$ types show the lower and higher alumina and TIO content, respectively

4.2. Kaolinite is essential mineral in F type while with minor content in A and S types. Calcium montmorillonite is observed in $\mathrm{F}$ type while sodium montmorillonite is detected in both samples of $\mathrm{S}$ and A types

4.3. $\mathrm{PH}$ value results refer to the $\mathrm{F}$ type is slightly below 
7 which mean that is neutral while the $\mathrm{S}$ and A samples are above 8 which indicate that is slightly basic. This might be taken as indication to the presence of sodium montmorillonite rich clay

4.4. Clays are recalculated on calcined basis and plotted on Riley, s composition diagram, all exist in the field of bloating.

4.5. Lightweight aggregates of low bulk density could be produced by firing the $\mathrm{A}$ and $\mathrm{S}$ samples up to $1150^{\circ} \mathrm{C}$ using a rate of heating $20^{\circ} \mathrm{C} / \mathrm{min}$.

4.6. Bulk density and crushing strength results of the A and $\mathrm{S}$ concretes results indicate the possibility of producing lightweight concretes blocks of low density and relatively good strength could be utilized in modern building trend for dead - load construction and in partition - wall construction as well as improve the thermal insulation of buildings.

\section{Acknowledgments}

The authors are greatly indebted to the National Research centre for financial support this research paper through the project No. 10130201.

\section{References}

[1] Said, R., (1990): The geology of Egypt, $2^{\text {nd }}$ Ed., A. A. Balkeema publishers, Rotterdam, Netherlands.

[2] Grim, R. E. (1962): Applied clay mineralogy, Mc Graw Hill Book Comp., Inc., New York Toronto, London.

[3] Grim, R. E. (1968): Clay mineralogy, $2^{\text {nd }}$ ed., Mc Graw Hill Book Comp., Inc., New York Toronto, London

[4] Grimshaw, R. W., (1971): The chemistry and physics of clays and other Ceramic Materials, Ernest Benn, London.

[5] Norton, F. H., (1969): Refractories, $4^{\text {th }}$ Ed., Mc Graw Hill Book Comp., Inc., New York Toronto, London
[6] Konta, J., (1979): Properties of Ceramic raw materials, Monograph 1.1.4 in: Ceramic monographs Hand Book of Ceramic, Verlag Schmid Gmbh, Freierg i. Brg.

[7] Serry, M. A., Hegab, M. and Elbana, M. M., (1985): Lightweight clay aggregates from wadi El- Natrun clays (Egypt) Sprechsael v. 118, N11

[8] Konta, J. (1995) Clay and man: Clay raw materials in the service of man , Applied Clay Science 10, 275-335

[9] Karaman S., Gunal, H. and Ersahin S. (2006) Assesment of clay bricks compressive strength using quantitative values of colour components, Construction and Building Materials $20,348-354$

[10] Bernhardt, M., et al. (2013) Mechanical properties of lightweight aggregates Journal of the European Ceramic Society $332731-2743$

[11] Plummer, Norman, and Hladik, W. B«, (1951) The manufacture of lightweight concrete from Kansas clays and shales: Kansas Geol, Survey Bull. 91, 100 pp.

[12] Prokopovich,Nikola, and Schwartz, G, M, (1957) Preliminary survey of bloating clays 'and shales of Minnesota: Minnesota Geol. Survey Summary Rept, 69 pp.

[13] Riley, C* M. (1951) Relation of chemical properties to the bloating of clays: Jour. Amer. Ceramic Society, vol. 34, pp. 121-128.

[14] Sullivan, $\mathrm{J}_{\ll} \mathrm{D} »$, et al. (1942) Expanded clay products: Mining Technology, vol. 6, no, 4, T. P. 1485, 10 pp.

[15] White, W. A. (I960) Lightweight aggregate from Illinois shales: Illinois State Geol. Survey Circ. 290, 29 pp.

[16] Conley, J. E., et al. (1948) Production of lightweight concrete aggregates from clays, shales, slates, and other materials: U. S, Bur, Mines Rept. Invest, 4401, 121 pp.

[17] British standard 2028. (1968) precast concrete blocks, British standard institution. 